\title{
PERILAKU RUMAH TRADISIONAL JAWA “JOGLO” TERHADAP GEMPA
}

\author{
Yulianto P. Prihatmaji \\ Jurusan Arsitektur Universitas Islam Indonesia Yogyakarta
}

\begin{abstract}
ABSTRAK
Rumah tradisional Jawa terletak di daerah gempa III (gempa sedang), terhampar dari Banyuwangi sampai Cirebon. Rumah tradisional Jawa berwujud Joglo secara bentuk dan konstruksi dianggap sebagai master piece rumah tradisional Jawa, yang terkesan berat dengan struktur rong-rongan (umpak-soko guru-tumpang sari) sebagai penahan beban lateral. Apabila terjadi gempa struktur kayu rong-rongan rumah Joglo dipandang sebagai struktur inti (core in frame) yang akan menahan gaya lateral, didukung oleh fleksibilitas, redaman, stabilitas, elastisitas, daktilitas, kehiperstatisan kayu dan konstruksi. Sistem tumpuan yang bersifat sendi dan atau rol, sistem sambungan lidah alur, konfigurasi soko-soko emper terhadap soko guru dan kekakuan soko guru oleh tumpang sari/brunjung dipandang sebagai kesatuan sistem earthquake responsive building. Hasil pengujian model struktur rong-rongan terhadap getaran gaya gempa dengan horizontal slip table, menunjukkan bahwa sistem pembebanan yang diterapkan di rumah Joglo menyumbang kestabilan, pada gempa frekuensi tinggi dan akselerasi rendah-tinggi. Pada getaran gaya gempa berfrekuensi rendah dan akselerasi rendah-tinggi, sistem pembebanan membuat model lebih banyak mengalami deformasi. Hasil penelitian menunjukkan bahwa, struktur rumah Joglo aman untuk daerah zona gempa 3 (apabila sistem tumpuan dibuat jepit).
\end{abstract}

Kata kunci: struktur joglo, konstruksi rong-rongan, sistem sambungan dan tumpuan, gaya gempa.

\section{ABSTRACT}

Javanese traditional house is located on earthquake zone 3 (midlle level), it spread from Banyuwangi (on East direction) until Cirebon (on West direction). Refer to form and construction system, the Joglo type house look a master piece of Javanese traditional house. It has impression of weight construction with rong-rongan structure (core in frame system from umpak-soko guru-tumpang sari) as vertical structure system. When earthquake come, wood structure of-rongan of Joglo house as a core structure or core in frame, it's a restrain to lateral force and depending on flexibility, brakebility, stability, elasticity and hiperstaticity of material and construction. The foundation system has hinge character or roll, connection system of tongue and gully configuration of secondary column (soko emper) and main column (soko guru), rigidity of main column (soko guru) from multy beam frame (tumpangsari/brunjung) are unity as earthquake responsive building. The test result of structure model of rong-rongan by vibration of earthquake force from horizontal slip table, is showed application of load system on Javanese traditional house support to stability. It has require on high frequency and acceleration low to high. Test on a vibration with low frequency and acceleration low to high, the load system make more deformation to model. The result of research is showed the structure of traditional Javanese house is safe on earthquake zone 3 (if base founfation maked clamp system).

Keywords: structure of joglo, construction of rong-rongan, connection and foundation system, earthqukae force.

\section{PENDAHULUAN}

Pada masyarakat Jawa yang rural agraris, pengetahuan membangun rumah dilakukan secara turun temurun (tradisi) dengan menggabungkan satu bahan dengan bahan lain dalam bentuk konstruksi berdasarkan perhitungan rasional (tektonika) (Nasution, 2001). Pembangunan rumah tersebut dilakukan dengan cara yang sederhana (teknologi lokal) dan menggunakan bahan alami (lokal). Mereka membuat bangunan yang dibutuhkan dengan cara coba-coba (trial and error) (Ronald, 1988), walaupun dengan perhitungan-perhitungan tertentu (petungan) (Prijotomo, 1995). Trial and error ini untuk antisipasi dan evaluasi rumah Jawa terhadap perubahan, baik perubahan dari luar rumah (alam, iklim, sosial dan budaya) dan dari dalam (penghuni: ekonomi, pendidikan dan agama) (Rapoport, 1969). Penerapan trial and error dalam rumah Jawa untuk antisipasi dan evaluasi terhadap alam, khususnya gempa bumi memiliki kekhasan penyelesaian struktur dan teknik konstruksinya. Hal ini karena wilayah Jawa termasuk daerah gempa III atau gempa sedang (DPU, 2002).

Gempa bumi menghasilkan getaran, berupa : gelombang primary yang bergetar berhimpitan dengan arah rambatan, gelombang secondary yang bergerak tegak lurus arah rambatan dan gelombang large yang berjalan di permukaan tanah (Mangunwijaya, 1988). Getaran gempa tersebut akan berpengaruh terhadap bangunan, berupa: gaya inersia (ditimbulkan oleh percepatan gempa terhadap massa bangunan) menyebabkan bangunan bergetar sesuai 
getaran tanah, gaya guling (disebabkan oleh gaya S yang berulang bolak-balik) mengakibatkan bangunan menekuk di bagian bawah dan gaya torsi (disebabkan dari perbedaan letak pusat kekauan massa dan pusat gempa) menjadikan bangunan berputar terhadap sumbu x (Subekti, 1997). Reaksi bangunan kayu terhadap gempa, berupa: fleksibilitas (kekauan dan keliatan) yaitu kekauan unsur atau sambungannya yang membentuk keliatan; redaman dan stabilitas (friction dan pegas) yaitu penyerapan getaran untuk melawan gaya inersia; elastisitas dan duktilitas, yaitu kemampuan bangunan untuk melakukan deformasi plastis tanpa runtuh; dan kehiperstatisan yang dibuat oleh unsur balok yang membentuk sendi plastis (Wangsadinata, 1975).

Berdasarkan sejarah perkembangan bentuk, rumah Jawa terdiri dari empat macam, yaitu Panggangpe, Kampung, Limasan dan Joglo (Hamzuri, 1982). Bentuk Tajug tidak dipakai untuk rumah tempat tinggal, tetapi untuk tempat beribadah. Macam bentuk rumah Jawa ini dipengaruhi oleh kondisi sosial budaya dan tingkat ekonomi, tingkat pendidikan (teknologi membangun), tingkat kepahaman akan agama, adat istiadat, kepercayaan, kondisi iklim, kondisi alam dan lingkungan serta ketersediaan bahan bangunan. Keempat macam bentuk rumah tradisonal Jawa menggunakan bahan yang sama yaitu kayu olahan (jati, nangka, tahun, glugu) dan bambu (Hamzuri, tt). Nama bentuk rumah tersebut sebenarnya merupakan nama bentuk atap rumah tradisional Jawa (Dakung, 1981). Bentuk Joglo dari segi bentuk dianggap sebagai master piece karya masyarakat Jawa (Hamzuri, 1982; Dakung, 1981; Ismunandar, 1986). Dari segi kompleksitas sistem struktur dan sistem sambungan, Joglo dan Tajug dinyatakan sebagai bentuk yang paling rumit dan lengkap (Prihatmaji, 2002). Berdasarkan sistem membangun dan bahan bangunan yang dipergunakan dalam membangun rumah tradisonal Jawa, maka bangunan yang dihasilkan mempunyai kesamaan dalam segi penyelesaian struktur dan teknik konstruksinya (Siddiq, 2002), walaupun dari segi bentuk dan gaya arsitekturnya berbeda satu sama lain.

Dalam tahapan menetap (nomadic-menetapbermasyarakat), tantangan klimatologis-geografis, faktor social budaya, kehidupan perekonomian dan material-teknik membangun menjadi pertimbangan untuk menjadikan arsitektur sebagai tempat yang manusiawi, nyaman dan sebagai ungkapan identitas sosial dan status. Tujuan seperti itu harus ditunjang dengan pengutamaan kualitas dan keawetan. Bentuk arsitektur dipengaruhi oleh tekanan dan tantangan lingkungan (kondisi klimatologis-geografis), kemudian mencari alternatif pemecahan melalui teknologi sumber-sumber, dan akan menghasilkan kekhasan bentuk langgam arsitektur sebagai bentuk strategi adaptasi (Rapoport, 1969).

Bentuk Joglo mempunyai sistem struktur penahan beban lateral yang berbeda dengan rumah tradisional Jawa lainnya. Perbedaan itu terletak pada struktur penahan gaya lateral melalui pembebanan pusat bangunan yang berupa soko guru dan tumpang sari (Frick, 1998), dengan tujuan agar bangunan menjadi berat dan stabil bila terkena gaya lateral. Kestabilan kuda-kuda soko guru dijamin dengan angka keamanan yang cukup tinggi (Ronald, 1988). Jumsai (1988) menyatakan bahwa rumah-rumah tradisional di Siam dan Pasifik Barat cenderung berkonstruksi dan berbahan ringan (lightweight construction-organic). Pada bentuk Joglo sebaliknya, terkesan berkonstruksi berat walaupun berbahan ringan (kayu).

Hal ini menjadi pertanyaan, karena salah satu usaha untuk mengurangi efek gaya inersia adalah dengan meringanlenturkan struktur konstruksi, sedangkan pada rumah Joglo berlawanan. Struktur atap Joglo seperti payung (umbrella system) (Pont, 1923) sehingga diperkirakan beban ini selaku pendulum untuk balancing system terhadap gaya gempa. Penggunaan umpak diasumsikan sebagai selected base isolation agar mengurangi getaran tanah pada bangunan keseluruhan. Hal ini karena bangunan Jawa merupakan organisme yang utuh (DPU, tt) dan menerapkan sistem meru (kepala; atap, badan : tiang, kaki: umpak) (Frick, 1997), sehingga bangunan terbagi 3 bagian yang dihubungkan dengan sambungan. Dalam kaitan konstruksi tahan gempa, sambungan antar elemen merupakan titik kritis.

Berdasarkan uraian diatas maka hipotesa yang diajukan dalam penelitian ini adalah: "sistem sambungan dan sistem pembebanan pada struktur rong-rongan (soko guru-blandar pengeret-sunduk kili) rumah tradisional Jawa dapat mengatasi gaya gempa”.

Terdapat dua sistem struktur penahan gaya lateral pada rumah tradisional Jawa, yaitu dengan ikatan balok-kolom (struktur rangka portal ruang/ struktur rong-rongan: tumpang sari-soko guruumpak) dan pembebanan supaya bangunan menjadi berat dan stabil untuk menahan gaya lateral. Sistem sambungan lidah alur yang digunakan pada rumah tradisional Jawa secara konstruktif lemah terhadap gaya lateral. Permasalahan yang diajukan adalah bagaimana perilaku dan kinerja struktur rong-rongan dalam menghadapi gempa, dan faktor-faktor apa sajakah yang mempengaruhinya.

Berdasarkan rumusan masalah yang ingin diselesaikan maka tujuan penelitian yang akan dicapai adalah, a. Mengetahui perilaku struktur rumah tradisional Jawa terhadap gaya gempa, b. Memperoleh 
gambaran pengaruh pembebanan pada struktur penahan gaya lateral (struktur rong-rongan rumah Joglo) terhadap gaya gempa, c. Menyelidiki faktorfaktor perilaku rumah tardisonal Jawa terhadap gaya gempa

Sesuai tujuan penelitian yang ingin diraih maka diharapkan penelitian ini bermanfaat untuk, a. Mendapatkan pengetahuan tentang kinerja struktur rong-rongan rumah Joglo, b. Mendapatkan faktor penyebab stabil-labilnya rumah Joglo, c. Mendapatkan sistem struktur sesuai dengan daerah gempa III (gempa sedang).

\section{KAJIAN PUSTAKA DAN TEORI}

Berdasarkan penelitian sebelumnya, secara hitungan matematis dan logika mekanika bentuk rumah Joglo mempunyai nilai keamanan yang tinggi (Pont, 1923) dan memiliki kestabilan yang cukup terhadap gaya gempa (Ronald, 1987), tetapi melihat profil dan sifat sambungannya juga mengandung kelemahan terhadap beban lateral (Frick, 1997 : 163-
164). Inti kekuatan struktur bentuk rumah Joglo adalah pada struktur rong-rongan (umpak-soko gurublandar) dan kekakuannya diperoleh dengan penerapan struktur rangka ruang (soko samping-blandarusuk), dan kombinasi struktur ini dianggap sebagai struktur core in frame (Siddiq, 2002).

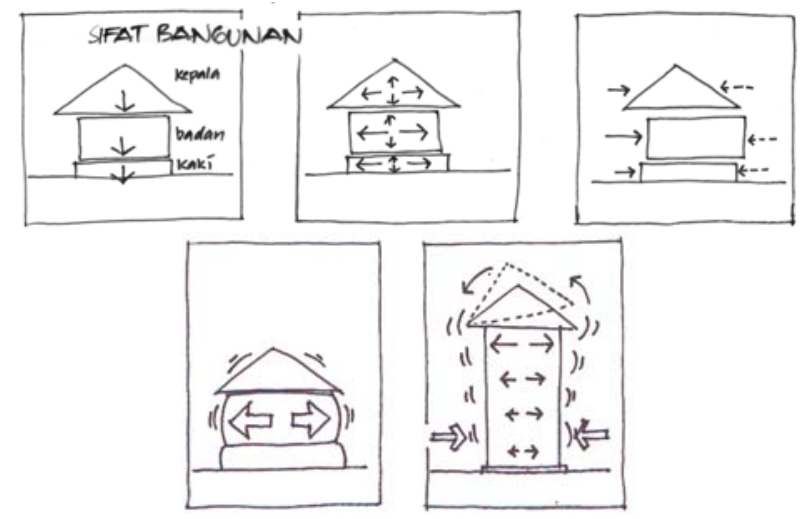

Sumber: DPU Bali, tt

Gambar 1. Aksi Gaya Gempa pada Rumah Tradisonal Jawa

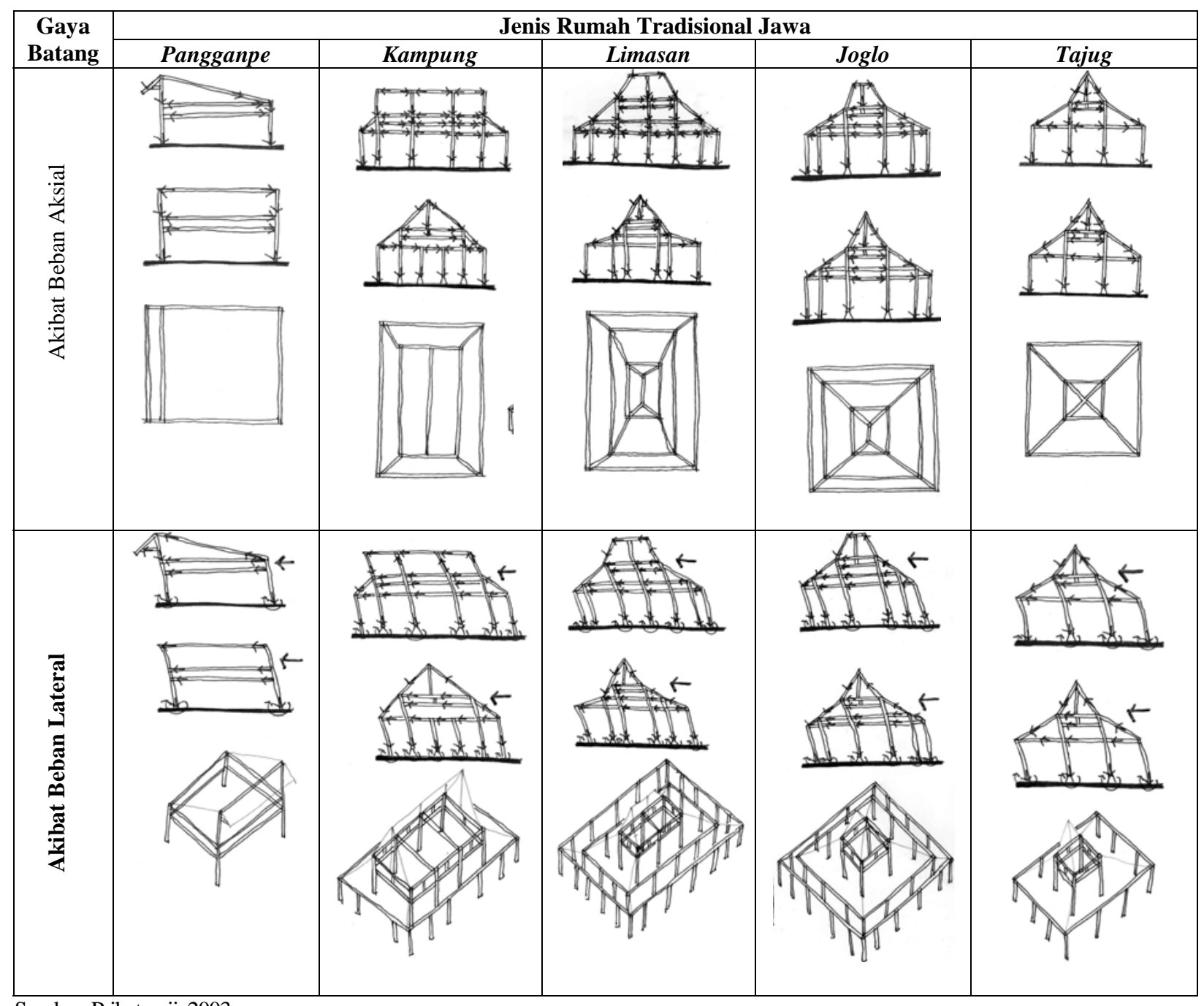

Sumber: Prihatmaji, 2003

Gambar 2. Reaksi Rumah Tradisional Jawa Terhadap Gaya Lateral dan Beban Sendiri 
Dalam kaitan struktur bangunan yang tahan gempa, titik kritis terletak di sambungan (Siddiq, 2001). Pada bentuk rumah Joglo sambungan terdapat pada pertemuan umpak-soko guru yang bersifat sendi, dan soko guru-blandar-sunduk-atap yang bersifat jepit terbatas. Kombinasi dua sifat sambunan ini dapat mengatasi gaya gempa, dimana sifat sendi pada umpak sebagai upaya mengurangi getaran gempa yang sampai ke soko guru (base isolation) dan sifat jepit pada blandar menjadikan atap berlaku seperti bandul untuk menstabilkan bangunan ketika menerima gaya gempa (pendulum), serta kedua sambungan tersebut menimbulkan friksi (friction) sebagai peredam getaran dan merupakan sarana disipasi energi (Prihatmaji, 2003).

Dalam hubungan arsitektur dan budaya, rumah tradisional Jawa dipandang sebagai bentuk strategi adaptasi terhadap alam (gempa) melalui rekayasa struktur konstruksi (sistem sambungan dan tumpuan) dan eksplorasi material lokal (batu, kayu dan bambu) (Rapoport, 1969). Rumah tadisional Jawa, lingkungan binaan dipandang bukan sekedar ekspresi fisik dari fasad dan ekpose konstruksi, melainkan juga kesesuaian dengan alam nyata (mikrokosmos-buana alit, yang didalamnya terdapat iklim dan topografi) dan alam maya (makrokosmos-buana ageng) (Frick, 1997).
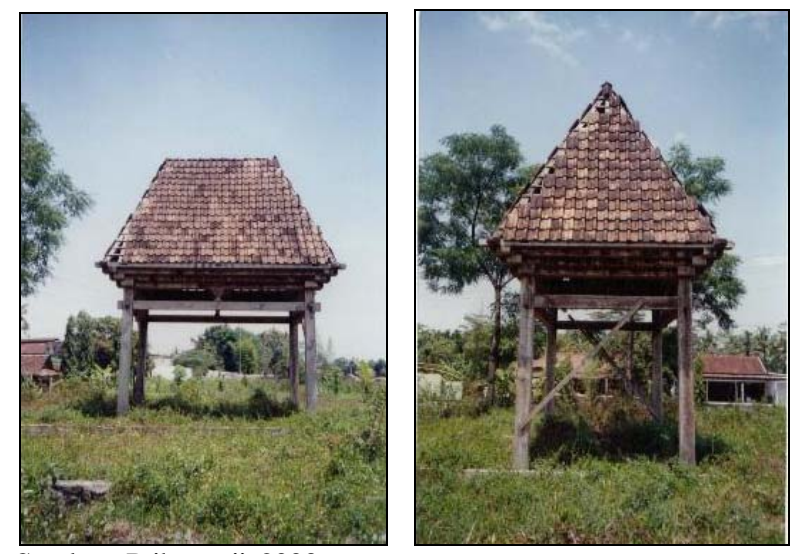

Sumber : Prihatmaji, 2003

\section{Gambar 3. Prototip Struktur Rong-Rongan skala} $1: 1$

Berkaitan dengan pengaruh gempa terhadap penentuan sistem struktur, penampilan dan bentuk arsitektur, rumah tradisional Jawa mempunyai kecenderungan ke arah saling berhubungan, baik dari detail elemen struktur, konfigurasi denah maupun proporsi bangunannya (Glasser, 1976; Howard, 1966). Kesesuaian rumah tradisional Jawa antara kebutuhan tempat tinggal yang aman dari gangguan alam gempa bumi (secara struktur) dengan tampilan bangunan yang selaras dengan budayanya (arsitektur) dapat dilihat pada detail struktur dan penampilan interior-eksteriornya (Prihatmaji, 2003).



Sumber: Frick, 1997

\section{Gambar 4. Struktur Rong-Rongan dari dalam Rumah Joglo}


Sumber : Leedam, 1969

Gambar 5. Detail Sambungan Struktur RongRongan 


\section{METODE PENELITIAN}

Berdasarkan tujuan penelitian ini, yaitu memperoleh gambaran pengaruh gempa pada rumah tadisional Jawa, mengetahui perilaku struktur rumah tradisional Jawa terhadap gaya gempa dan menyelidiki faktor-faktor perilakunya secara valid dan nyata, maka metode yang digunakan adalah metode ekperimental skala laboratorium. Metode eksperimental skala laboratorium adalah observasi dibawah kondisi buatan (artificial condition) yang diatur dan dibuat mendekati keadaan sebenarnya dengan memanipulasi variabel dan obyek yang terkontrol (Nazir, 1988:74). Tujuan penelitian eksperimental adalah untuk menyelidiki ada tidaknya dan seberapa besar hubungan sebab akibat, dengan cara memberikan perlakuan-perlakuan tertentu pada percobaan dan menyediakan kontrol untuk perbandingan. Percobaan ini dilakukan untuk menguji hipotesa dan sebagai usaha menemukan hubungan kausal yang baru yang dapat menguatkan atau mengubah teori-teori sebelumnya.

\section{Rancangan Penelitian}

Desain penelitian ini adalah desain percobaan yang mempunyai kontrol, dimana beberapa variabel dikontrol dan beberapa yang lain merupakan kontrol (Nazir, 1988:104). Dalam percoban ini diadakan manipulasi terhadap beberapa variabel atau faktor yang merupakan fenomena penyebab munculnya hasil yang sedang diteliti, antara lain :

a. Untuk mendapatkan mechanical properties dilakukan dengan membuat benda uji dari kayu elemen struktur rong-rongan untuk mendapatkan kuat tarik, kuat tekan, kuat geser dan modulus elastisitasnya. Benda-benda uji di letakkan di mesin penguji dan dikenai gaya tekan, tarik dan geser.

b. Untuk memperoleh gambaran perilaku dan kinerja struktur rong-rongan terhadap pengaruh gaya gempa, dilakukan dengan meletakkan benda uji struktur rong-rongan skala 1:1 di base foot, kemudian diberikan gaya horizontal/ateral seismic dengan alat horizontal slip table. Hasil pengujian adalah besarnya tegangan pada masing-masing elemen struktur rong-rongan yang digunakan untuk meraih tujuan.

\section{Variabel Penelitian}

Dalam penelitian ini, terdapat hubungan dua variabel, yaitu perilaku rumah tradisional Jawa terhadap gempa, maka digunakan variabel bebas (antecedent/sebab) dan variabel dependent (konsekuensi/akibat). Dalam penelitian ini, variabel bebas- nya adalah pengaruh gempa yang teridiri dari getaran gaya gempa dan aksinya, yaitu gaya horizontal/ateral seismic, gaya inersia, gaya torsi dan gaya guling. Variabel dependennya adalah reaksi rumah tradisional Jawa terhadap gempa, yang berintikan struktur rong-rongan (umpak-soko guru-tumpang sari), yang meliputi jenis, sifat, perilaku dan kinerja sambungan didalamnya. Titik kritis konsep struktur tahan gempa adalah pada sambungannya (Siddiq, 2001).

\section{Tahapan dan Langkah Penelitian}

Untuk memahami perilaku dan kinerja struktur rong-rongan, terlebih dulu diketahui mechanical properties-nya (kayu jati) yang mencakup kuat lentur, kuat tekan, kuat tarik dan kuat geser. Ke-empat mechanical properties ini yang akan digunakan dalam menentukan kelas kuat kayu dan untuk membahas perilaku dan kinerja struktur rong-rongan.

Gambaran perilaku struktur rong-rongan terhadap gaya gempa dan faktor-faktornya akan menjawab permasalahan tentang bagaimana pengaruh gempa pada rumah tradisional Jawa. Gambaran yang valid dan nyata tersebut diperoleh dengan percobaan skala laboratorium yang dikondisikan mendekati keadaan getaran gaya gempa sebenarnya. Percobaan akan meneliti obyek uji sebagai inti struktur rumah tardsional Jawa, yang diberikan getaran gaya gempa buatan. Jumlah dan jenis perlakuan aksi gaya gempa dilakukan sampai obyek uji mengalami deformasi maksimal tidak sampai runtuh. Pembahasannya meliputi reaksi benda uji terhadap gempa yang berupa sifat, perilaku, kinerja sambungan dan deformasi bentuk model.

Kemudian struktur rong-rongan diberi aksi gaya gempa berupa gaya lateral seismic/horizontal sampai deformasi maskimal tanpa keruntuhan. Alat-alat pencatat reaksi (sensor) yang dipasang pada model struktur rong-rongan dan shaking table (pada base, soko guru tengah dan atas) akan merekam regangan dan simpangan. Hasil pencatatan ini dikirim ke mesin pencatat dan menghasilkan print out yang akan digunakan untuk melihat spectrum getaran gaya gaya gempa.

\section{Strategi Penentuan Model}

Model benda uji dianggap sebagai mock up yang representatif dari inti struktur rumah tradisional Jawa. Hasil penelitian sebelumnya menyatakan bahwa rumah tradisional Jawa memiliki kesamaan pada tipe struktur bangunan dan berbeda pada jenis struktur penahan beban lateral, dimana bentuk Joglo menggunakan struktur penahan beban lateral dengan pembebanan (Frick, 1997). Sistem rumah tradisional Jawa berintikan bentuk pendopo (Pont, 1923) atau 
mandapa (Indorf, 1991), yang memiliki kompleksitas sambungan (Prihatmaji, 2002), yang memiliki nilai keamanan yang cukup (Ronald, 1987) dan secara konstruktif lemah terhadap beban lateral (Siddiq, 2001). Berdasarkan hal tersebut, maka bentuk pendopo yang berstruktur rong-rongan memiliki kekuatan dan kelemahan secara analitis matematis (statistika mekanika), dan perlu dibuktikan secara nyata melalui uji eksperimental terskala, sehingga validitas dan reabilitasnya dapat dipertanggungjawabkan.

\section{Skala Model}

Model pada penelitian ini adalah 'design model', yaitu model yang digunakan untuk memberi proporsi pada komponen-komponen sistem struktur prototip (rong-rongan) (Pedju, 1993 ; Hossdorf,1974 ; Merati, 1990). Hukum skala (Laws of Similitude) model ini antara lain : skala modulus elastisitas $\left(f_{\mathrm{E}}\right)$ adalah $\mathrm{E}$ model berbanding lurus E prototip, yaitu 1 (karena bahan yang digunakan sama dan homogenitasnya dapat dijamin). Skala variabel dimensi panjang adalah $f_{\mathrm{r}}=\mathrm{r}_{\mathrm{m}} / \mathrm{r}_{\mathrm{p}}=1 / 5$, jadi skala panjangnya $1: 5$. Skala variabel gayanya adalah $\mathrm{P}_{\mathrm{m}}=f_{\mathrm{E}} f_{\mathrm{r}}^{2} \mathrm{P}_{\mathrm{p}}$, jadi $f_{\mathrm{P}}=\mathrm{P}_{\mathrm{m}} /$ $\mathrm{P}_{\mathrm{p}}=1 \times 1^{2} / 5^{2}=1 / 25$, jadi skala gayanya adalah $1: 25$ (ini berarti, gaya $\mathrm{P}$ sebesar $1 \mathrm{~kg}$ di model adalah sebesar $25 \mathrm{~kg}$ di prototip).

Kesetaraan model dan prototip terletak pada properti bahan skala panjang (quantity metric scale), sedangkan skala mutu (quality scale) pada penelitian ini diabaikan. Dalam hal penelitian untuk melihat kinerja sistem bukan kualitas sistem hal ini dapat diterima (Pedju, 1993). Model seperti ini dipergunakan untuk menggambarkan kinerja sebuah sistem struktur, bukan untuk mendapatkan kualitas sistem struktur.

\section{Alat dan Bahan Penelitian}

a. Base foot dari baja (steel pedestal) sejumlah 4 buah.

b. Tempat beban (bak pasir) kapasitas $250 \mathrm{~kg}$ sebanyak 1 buah (luas bidang atap model $50 \mathrm{~m}^{2} \mathrm{x}$ berat $/ \mathrm{m}^{2}$ bidang atap genteng $50 \mathrm{~kg} / \mathrm{m}^{2}=250 \mathrm{~kg}$ ).

Untuk mendapatkan perilaku dan kinerja struktur rong-rongan terhadap gaya gempa, maka digunakan alat:

a. Horizontal slip table atau shaking table dan control panel sebagai alat input data frekuensi, akselerasi dan waktu getaran gaya gempa.

b. Sensor untuk mendeteksi simpangan getaran gempa, c. Amplifier, recorder dan komputer untuk mencatat deteksi dari sensor serta memvisualkan angka menjadi tabel data dan grafik.

Pertama, model dengan beban $250 \mathrm{~kg}$ (bak pasir sebagai beban atap), dipasang di base foot dari pelat baja dan diletakkan di shaking table dengan baut. Kedua, alat sensor dipasang di base foot, soko guru bagian tengah dan atas. Ketiga, panel control di seting frekuensi fix (konstan) $10.0 \mathrm{~Hz}$ dengan akselerasi meningkat dari $0.001-0.009,0.010-0.090,0.100$ 0.190 dan $0.200-0.290 \mathrm{G}$.

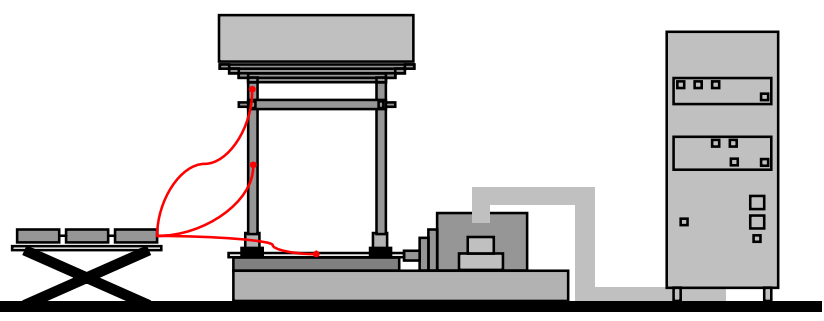

Gambar 6. Skema Rancangan Pengujian Model Struktur Rong-Rongan dengan Horizontal Slip Table

Penentuan frekuensi fix berdasarkan kebutuhan pengujian dan kemudahan pengoperasian, dan nilai $10.0 \mathrm{~Hz}$ berdasar dari rumus $\mathrm{T}$ (time history) $=0.10 \mathrm{~N}$ (jumlah lantai). Penjabaran rumus tersebut adalah $\mathrm{T}=$ $0.10 \times 1=0.1$. Kemudian mencari $\mathrm{f}($ frekuensi $)=1 / \mathrm{T}$, jadi $\mathrm{f}=1 / 0.10=10 \mathrm{~Hz}$. Frekuensi ini digunakan untuk mencari $\mathrm{F}$ (force) gaya gempa. Keempat, pengujian di rekam handy cam, untuk melihat ulang rinci perilaku model dari pengaruh dari getaran gaya gempa.

\section{HASIL DAN BAHASAN}

\section{Hasil Pengujian}

Istilah stabil pada model, dalam pembahasan ini, berarti model secara visual terlihat tidak bergetar dan istilah labil menunjukkan model secara visual terlihat bergetar atau bergoyang. Istilah deformasi menunjukkan bahwa model mengalami perubahan bentuk, condong ke kanan atau ke kiri. Istilah disipasi energi, menunjukkan bahwa telah terjadi pelepasan enerji pada bagian tertentu untuk mengurangi getaran atau disebut redaman.

Pada perlakuan 1, model stabil, deformasi tidak terjadi dan sambungan tetap utuh. Perlakuan 2, model stabil pada mulanya dan pada akselerasi 0.90 mengalami deformasi ke kanan $2 \mathrm{~mm}$, keadaan sambungan utuh. Dalam perlakuan 3, model mengalami deformasi ke kanan $10 \mathrm{~mm}$ pada akselerasi 1.30 G, model kembali ke posisi semula pada akselerasi 
$1.70 \mathrm{G}$ dan terus mengalami deformasi ke kiri sampai akselerasi $1.90 \mathrm{G}$, serta sambungan tetap utuh. Perlakuan 4, model mengalami deformasi ke kiri 18 mm pada akselerasi $2.30 \mathrm{G}$, dan setelah itu mengalami deformasi ke kanan. Pada akselerasi 2.70 $\mathrm{G}$ mengalami deformasi ke kanan $1 \mathrm{~mm}$, serta sambungan masih utuh.

Pada perlakuan 1 sampai 4, secara visual yang bergerak hanya tiang atau soko gurunya saja, sedangkan bagian atas atau sambungan blandarpengeret-tumpang sari terlihat tak bergerak. Hal ini menunjukkan vertical load system bekerja pada sistem struktur rong-rongan ini. Dengan kata lain beban memberikan sumbangan kestabilan pada struktur rong-rongan ini. Sistem sambungan soko guru-blandar-pengeret dan soko guru-sunduk-kili tidak mengalami perubahan. Hal ini memperlihatkan bahwa sistem sambungan lidah dan alur pada struktur rong-rongan cukup kuat dan stabil terhadap getaran gaya gempa yang ditimbulkan oleh shaking table. Dari perlakuan 1 sampai 4, secara visual yang bergerak hanya soko guru atau dari sunduk-kili ke bawah. Hal ini menunjukkan bahwa sunduk dan kili menyumbang kekuatan dan kekakuan bagi struktur rong-rongan, dalam hal ini mendukung blandarpengeret. Dimensi penampang dan tinggi soko guru juga mempengaruhi kelenturan soko guru sendiri. Semakin tinggi dan kecil soko guru, relatif semakin lentur dan mampu meredam getaranagar tidak merambat ke bagian atas (tetapi beresiko patah : diperlukan ukuran proporsional), sehingga bagian atas cukup stabil.

Pada perlakuan 5, model bergerak ke kiri dan ke kanan mengikuti getaran shaking table, dari tiang atau soko guru sampai bagian atas atau tumpang saribrunjung, dan sambungan masih utuh. Model terdengar berderak pada bagian sambungan tumpang sari-brunjung dan blandar-pengeret. Perlakuan 5 menunjukkan perilaku model mengalami gaya inersia, dimana getaran gaya gempa dari shaking table sampai ke atas.

Perlakuan 1 sampai 4, input data shaking table dimasukkan frekuensi fix (konstan) $10.0 \mathrm{~Hz}$, akselerasi dipasang secara bertahap dari 0.001-0.290 $\mathrm{G}$ dan seting waktu disesuaikan dengan pencapaian akselerasi sampai konstan dari 10 detik untuk 0.0010.009, 20 detik untuk 0.010-0.90, 40 detik untuk 0.100-0.190 dan 60 detik untuk 0.200-0.290. Perlakuan 1 sampai 4 mempunyai frekuensi getaran yang tinggi dengan variasi akselerasi. Hal ini mengakibatkan getaran gaya gempa shaking table hanya sampai tiang saja, tidak sampai bagian atas. Dengan kata lain, disipasi energi dan redaman getaran terjadi pada soko guru. Bagian atas tidak mendapat getaran yang berarti, yang mengakibatkan struktur rong-rongan stabil.
Berbeda dengan perlakuan 1 sampai 4, perlakuan 5 mempunyai input data shaking table dengan frekuensi meningkat bertahap dari $1.0-10.0 \mathrm{~Hz}$, akselerasi dipasang pada .150 G (gempa zona 3) dengan waktu 30 menit (menyesuaikan pencapaian akselerasi konstan pada 0.150 G). Perlakuan 5 mempunyai frekuensi getaran rendah tetapi akselerasi tinggi. Hal ini mengakibatkan getaran dapat mencapai bagian atas, sehingga mengakibatkan kelabilan. Model mendapat gaya inersia dan disipasi energi terjadi merata pada seluruh bagian struktur rongrongan, dari soko guru sampai tumpang sari. Berarti perlakuan 5 dengan frekuensi rendah tetapi akselerasi tinggi lebih dapat menggoyang keseluruhan model struktur rong-rongan (gaya inersia) daripada perlakuan 1 sampai 4 yang berfrekuensi tinggi dengan akselerasi rendah-tinggi.

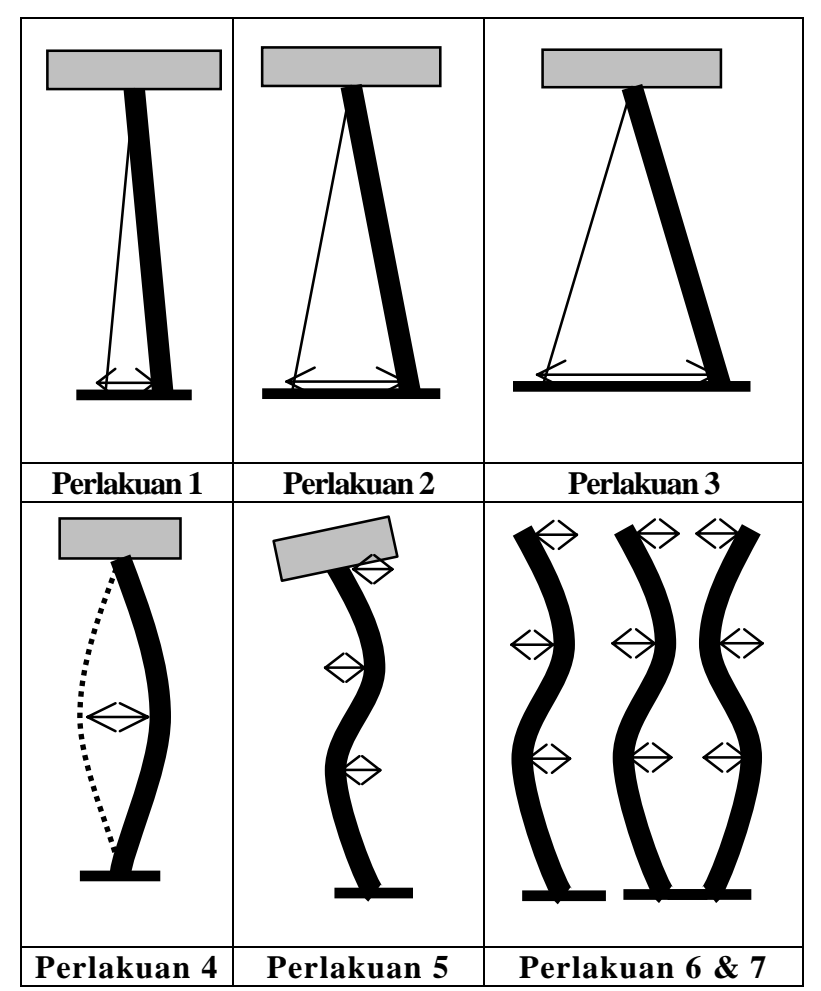

\section{Gambar 7. Skema Perilaku Model Uji Terhadap Gaya Gempa}

Pada perlakuan 6 dan 7, model diuji tanpa beban, menunjukkan model tidak mengalami deformasi dan sambungan tetap utuh, walaupun secara visual model terlihat bergoyang. Perlakuan 6 dengan frekuensi konstan $10.0 \mathrm{~Hz}$, akselerasi 0.003 $0.290 \mathrm{G}$ dan waktu 40 detik, mengakibatkan model terlihat tergetar secara visual pada akselerasi $0.60 \mathrm{G}$ dan bergoyang pada akselerasi 0.130 G. Perlakuan 7 dengan frekuensi $1.0-10.0 \mathrm{~Hz}$, akselerasi konstan $0.150 \mathrm{G}$ dan waktu 40 detik, mengakibatkan model bergoyang hebat (gerak 2 dimensi kiri-kanan) pada frekuensi $5.0 \mathrm{~Hz}$, dan bergoyang sangat hebat (gerak 
3 dimensi kiri-kanan-maju-mundur) pada frekuensi $2.0 \mathrm{~Hz}$

Secara visual perbandingan goyangan model dengan beban perlakuan $1-4$ dengan perlakuan 5, menunjukkan bahwa pembebanan memberikan kestabilan pada frekuensi rendah $(10.0 \mathrm{~Hz})$ dan pada frekuensi rendah $(5.0 \mathrm{~Hz})$ pembebanan mengakibatkan deformasi. Goyangan model tanpa beban pada perlakuan 6 dan 7, menunjukkan bahwa model tidak mengalami deformasi, walaupun model tergetar hebat (gerak 3 dimensi). Hal ini berarti struktur mempunyai sifat duktil dan bahan kayu memiliki sifat elastis yang baik, sehingga model dapat kembali pada bentuk semula tanpa mengalami deformasi bentuk.

Dengan berdasarkan data dan uraian diatas, maka hipotesa yang diajukan yaitu: "sistem sambungan dan sistem pembebanan pada struktur rong-rongan rumah tradisional Jawa dapat mengatasi gaya gempa” diterima atau hipotesa benar.

\section{Pembahasan}

Pada getaran gempa dengan shaking table berfrekuensi tinggi dan akselerasi rendah-tinggi, model struktur rong-rongan mengalami goyangan pada soko guru, sedangkan bagian atas stabil. Sistem sambungan lidah alur pada struktur rong-rongan tidak mengalami perubahan, karena getaran yang sampai kepadanya relatif kecil. Hal ini dikarenakan disipasi energi dan redaman terjadi pada soko guru. Sistem pembebanan dipandang menyumbang kestabilan pada model struktur rong-rongan.

Pada getaran gempa shaking table berfrekuensi rendah-tinggi dan akselerasi tinggi, model struktur rong-rongan mengalami goyangan menyeluruh dari bawah sampai atas (dari soko guru sampai tumpang sari). Sistem sambungan lidah alur dalam struktur inti tetap (lihat lampiran 5 dan 6), walaupun getaran sampai padanya. Hal ini berarti sistem sambungan lidah alur dalam struktur rong-rongan mampu menahan dan meredam getaran gaya gempa dan disipasi energi serta redaman terjadi pada soko guru dan pada sambungan soko guru-sunduk-kili, soko guru-blandar-pengeret dan pada blandar-pengerettumpang sari-brunjung. Sistem sambungan pen mampu menahan gaya horisontal dari getaran gaya gempa, sedangkan gaya vertikal di berikan oleh beban di atasnya.

Pembebanan memberikan kestabilan model struktur pada saat tidak terjadi getaran gempa dan pada getaran gempa berfrekuensi tinggi dengan akselerasi kurang dari $0.190 \mathrm{G}$ (gempa zona 3 : 0.150 G). Pada keadaan tersebut, getaran sepenuhnya diterima oleh soko guru sehingga duktilitas soko guru menjadi penting, karena disipasi energi terjadi pada soko guru. Apabila duktilitas soko guru tidak memadai maka, model mengalami kerusakan pada soko guru (patah) dan model akan runtuh. Jika duktulitas soko guru terjamin, maka getaran hanya sampai pada soko guru, sedangkan bagian atas tetap stabil karena pembebanan.

Pembebanan mengakibatkan deformasi pada model struktur apabila mengalami getaran gempa dengan frekuensi rendah $0.2-0.5 \mathrm{~Hz}$ dan akselerasi 0.150 G (gempa zona 3). Dalam keadaan ini, getaran terjadi di soko guru dan bagian atasnya dan disipasi energi terjadi di seluruh komponen model struktur (soko guru-sambungan-blandar pengeret-sunduk kilitumpang sari dan brunjung). Pada keadaan ini kelemahan terdapat pada kekuatan soko guru, sedangkan sambungan soko guru-blandar pengeret atau soko guru-sunduk kili atau blandar pengerettumpang sari-brunjung relatif stabil. Soko guru menerima gaya tarik dan tekuk dari getaran gaya gempa dan gaya tekan dari beban diatasnya serta gaya momen puntir dari bidang tumpang sari dan brunjung, sehingga kualitas dan dimensi kayu menentukan kekuatan dan kestabilan model strukur. semakin kecil dimensi kayu soko guru semakin lentur tetapi beresiko patah, sehingga dibutuhkan proporsi ukuran kayu yang aman terhadap kelenturan dan resiko patah.

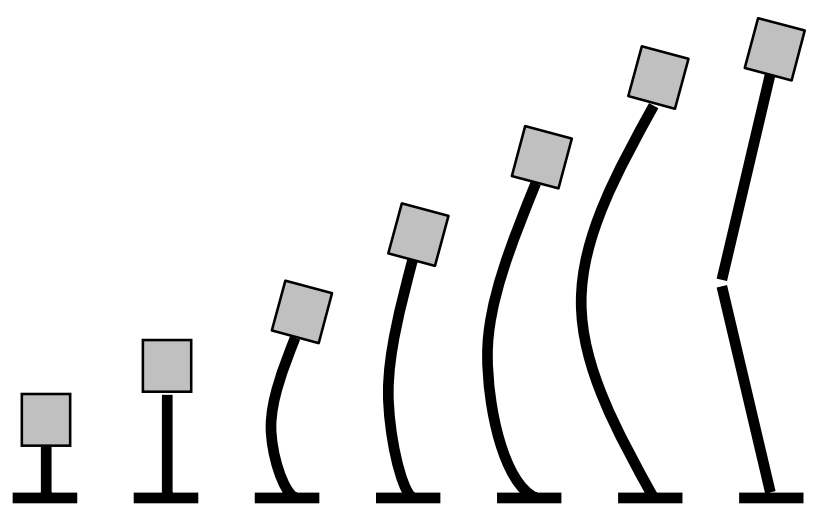

Sumber: Frick, 1998

Gambar 8. Perilaku Sistem Pembebanan Pada Bangunan (semakin tinggi bangunan semakin besar gaya tekuk sehingga mudah runtuh) 
Tabel 1. Perilaku Model Struktur Rong-Rongan Terhadap Getaran Gaya Gempa

\begin{tabular}{|c|c|c|c|}
\hline Perlakuan & Model & Deformasi & Sambungan \\
\hline 1 & Stabil & Tidak terjadi & Utuh \\
\hline 2 & Stabil & Akselerasi 0.90 deformasi ke kanan 2 mm & Utuh \\
\hline 3 & Labil & $\begin{array}{l}\text { Deformasi ke kanan } 10 \mathrm{~mm} \text { pada akselerasi } 1.30 \mathrm{~g} \\
\text { Kembali ke posisi semula pada akselerasi } 1.70 \mathrm{~g} \text { terus mengalami deformasi ke } \\
\text { kiri sampai akselerasi } 1.90 \mathrm{~g}: 5 \mathrm{~mm}\end{array}$ & Utuh \\
\hline 4 & Labil & $\begin{array}{l}\text { Deformasi ke kiri } 18 \mathrm{~mm} \text { pada akselerasi } 2.30 \mathrm{~g} \\
\text { Setelah itu mengalami deformasi ke kanan } \\
\text { Akselerasi } 2.70 \mathrm{~g} \text { mengalami deformasi ke kanan } 1 \mathrm{~mm}\end{array}$ & Utuh \\
\hline 5 & Labil & $\begin{array}{l}\text { Deformasi ke kiri 6mm pada frekuensi } 1 . \mathrm{Hz} \text { dan terus mengalami deformasi ke } \\
\text { kiri sampai } 20 \mathrm{~mm} \text { pada frekuensi } 10.0 \mathrm{hz}\end{array}$ & Utuh \\
\hline 6 & Labil & Tidak terjadi & Utuh \\
\hline 7 & Labil & Tidak terjadi & Utuh \\
\hline
\end{tabular}

Tabel 2. Perilaku Model dengan Beban Struktur Rong-Ronganterhadap Getaran Gaya Gempa

\begin{tabular}{|c|c|c|c|c|c|}
\hline $\begin{array}{l}\text { Getaran gempa } \\
\text { lengan shaking table }\end{array}$ & $\begin{array}{l}\text { Model struktur } \\
\text { rong-rongan }\end{array}$ & $\begin{array}{l}\text { Sistem sambungan } \\
\text { lidah alur }\end{array}$ & Disipasi energi & Sistem pembebanan & $\begin{array}{l}\text { Sistem sambungan } \\
\text { pen }\end{array}$ \\
\hline $\begin{array}{l}\text { Frekuensi tinggi dan } \\
\text { lkselerasi rendah- } \\
\text { inggi }\end{array}$ & $\begin{array}{l}\text { Bergoyang pada } \\
\text { soko guru-bagian } \\
\text { atas stabil }\end{array}$ & $\begin{array}{l}\text { Tetap karena } \\
\text { getarannya relatif kecil }\end{array}$ & Pada soko guru & $\begin{array}{l}\text { Menyumbang } \\
\text { kestabilan }\end{array}$ & $\begin{array}{l}\text { Mampu menahan } \\
\text { gaya horisontal, }\end{array}$ \\
\hline $\begin{array}{l}\text { Jetaran gempa dengan } \\
\text { haking table }\end{array}$ & $\begin{array}{l}\text { Model struktur rong- } \\
\text { rongan }\end{array}$ & $\begin{array}{l}\text { Sistem sambungan } \\
\text { lidah alur }\end{array}$ & Disipasi energi & Sistem pembebanan & $\begin{array}{l}\text { Sistem sambungan } \\
\text { pen }\end{array}$ \\
\hline $\begin{array}{l}\text { irekuensi rendah- } \\
\text { inggi dan akselerasi } \\
\text { inggi }\end{array}$ & $\begin{array}{l}\text { Bergoyang } \\
\text { menyeluruh dari } \\
\text { bawah -atas (soko } \\
\text { guru-tumpang sari) } \\
\text { Bergetar } 2 \text { dimensi } \\
\text { (kiri-kanan) }\end{array}$ & $\begin{array}{l}\text { Tetap, walaupun } \\
\text { mengalami getaran } \\
\text { Berarti mampu } \\
\text { menahan getaran gaya } \\
\text { gempa }\end{array}$ & $\begin{array}{l}\text { Pada soko guru dan } \\
\text { pada sambungan } \\
\text { soko guru-sunduk- } \\
\text { kili, soko guru- } \\
\text { blandar-pengeret dan } \\
\text { pada blandar- } \\
\text { pengeret-tumpang } \\
\text { sari-brunjung }\end{array}$ & $\begin{array}{l}\text { Memberikan gaya } \\
\text { aksial (vertikal) atau } \\
\text { beban sendiri } \\
\text { Menyumbang } \\
\text { deformasi model }\end{array}$ & $\begin{array}{l}\text { Mampu menahan } \\
\text { gaya horisontal, }\end{array}$ \\
\hline
\end{tabular}

Tabel 3. Perilaku Model Tanpa Beban Struktur Rong-Rongan Terhadap Getaran Gaya Gempa

\begin{tabular}{|l|l|l|l|l|}
\hline $\begin{array}{l}\text { Getaran gempa } \\
\text { shaking table }\end{array}$ & $\begin{array}{l}\text { Model struktur rong- } \\
\text { rongan }\end{array}$ & $\begin{array}{l}\text { Sistem sambungan } \\
\text { lidah alur }\end{array}$ & Disipasi energi & Sistem sambungan pen \\
\hline $\begin{array}{l}\text { Frekuensi tinggi } \\
\text { dan akselerasi } \\
\text { rendah-tinggi }\end{array}$ & $\begin{array}{l}\text { Bergoyang menyeluruh } \\
\text { dari bawah -atas (soko } \\
\text { guru-tumpang sari) }\end{array}$ & $\begin{array}{l}\text { Tetap, walaupun } \\
\text { mengalami getaran } \\
\text { Berarti mampu } \\
\text { menahan getaran gaya } \\
\text { gempa }\end{array}$ & $\begin{array}{l}\text { Pada soko guru dan pada } \\
\text { sambungan soko guru-sunduk- } \\
\text { kili, soko guru-blandar-pengeret } \\
\text { dan pada blandar-pengeret- } \\
\text { tumpang sari-brunjung }\end{array}$ & $\begin{array}{l}\text { Mampu menahan gaya } \\
\text { horisontal, }\end{array}$ \\
\hline $\begin{array}{l}\text { Frekuensi rendah- dimensi (kiri- } \\
\text { tinggi dan } \\
\text { akselerasi tinggi }\end{array}$ & $\begin{array}{l}\text { Bergoyang menyeluruh } \\
\text { dari bawah-atas (soko } \\
\text { guru -tumpang sari) } \\
\text { Bergetar 3 dimensi (kiri- } \\
\text { kanan; maju-mundur) }\end{array}$ & $\begin{array}{l}\text { Tetap, walaupun } \\
\text { mengalami getaran } \\
\text { Berarti mampu } \\
\text { menahan getaran gaya } \\
\text { gempa }\end{array}$ & $\begin{array}{l}\text { Pada soko guru dan pada } \\
\text { sambungan soko guru-sunduk- } \\
\text { kili, soko guru-blandar-pengeret } \\
\text { dan pada blandar-pengeret- } \\
\text { tumpang sari-brunjung }\end{array}$ & $\begin{array}{l}\text { Mampu menahan gaya } \\
\text { horisontal, }\end{array}$ \\
\hline
\end{tabular}

\section{KESIMPULAN DAN SARAN}

\section{Kesimpulan}

a. Perilaku struktur rong-rongan terhadap getaran gaya gempa berfrekuensi tinggi-akselerasi rendah adalah struktur stabil (secara visual tidak terlihat bergetar) tidak mengalami deformasi, sambungan utuh dan disipasi energi terjadi di soko guru.

b. Perilaku struktur rong-rongan terhadap getaran gaya gempa berfrekuensi tinggi dan akselerasi tinggi adalah struktur stabil (secara visual terlihat bergetar) tetapi terjadi deformasi, sambungan utuh dan disipasi energi terjadi pada soko guru.

c. Perilaku struktur rong-rongan terhadap getaran gaya gempa berfrekuensi rendah dan akselerasi tinggi adalah struktur labil (secara visual terlihat bergetar hebat) dan mengalami deformasi, sambungan utuh dan disipasi energi terjadi di soko guru, sunduk-kili, blandar-pengeret dan sambungan diantara ketiganya. 
d. Perilaku struktur rong-rongan terhadap getaran gaya gempa berfrekuensi rendah dan akselerasi rendah adalah struktur labil (secara visual terlihat bergetar sangat hebat) dan mengalami deformasi, sambungan utuh dan disipasi energi terjadi pada soko guru, sunduk-kili, blandar-pengeret dan sambungan diantara ketiganya.

e. Pembebanan pada struktur rong-rongan memberikan sumbangan kestabilan terhadap getaran gaya gempa berfrekuensi tinggi-akselerasi rendah dan berfrekuensi tinggi-akselerasi tinggi. Pada getaran gaya gempa berfrekuensi rendah-akselerasi tinggi dan frekuensi rendah-akselerasi rendah, pembebanan membuat struktur mengalami deformasi.

f. Fleksiblitas sambungan lidah alur dalam struktur rong-rongan, pada hubungan soko guru-blandar pengeret, soko guru-sunduk kili mampu meredam gaya lateral dari getaran gaya gempa. Sambungan lidah alur tersebut menimbulkan friksi antar elemen struktur. Akumulasi friksi 3 dimensi pada sambungan struktur inti (soko guru-blandar pengeret; soko guru-sunduk kili; blandar pengeret-tumpang sari-brunjung) merupakan redaman (toleransi getaran) yang mampu mengatasi kelemahan konstruktif sambungan terhadap getaran gaya gempa.

g. Struktur rumah tradisinal Jawa (Joglo) mampu menahan getaran gaya gempa zona 3 (time history zone 3 : frekuensi $10.0 \mathrm{~Hz}$, akselerasi $0.150 \mathrm{G}$ dan waktu 10 detik, jika sistem tumpuan dibuat jepit. Faktor kemampuan struktur rumah tradisional Jawa untuk menahan getaran gaya gempa adalah duktilitas kayu soko guru, kualitas konstruksi sambungan, dan proporsi lebar-panjang-tinggi struktur rong-rongan.

h. Konfigurasi letak dan teknik konstruksi struktur rong-rongan mempengaruhi simetrisitas denah dan proporsi tinggi rumah tradisional Jawa. Simetrisitas denah mengurangi aksi gaya torsi dan proporsi tinggi mengurangi aksi gaya guling akibat getaran gaya gempa.

i. Ekspose elemen struktur sebagai ornamen interior di dalam bangunan, dari bawah sampai atas (umpak, soko guru, blandar pngeret, sunduk kili, tumpang sari, brunjung dan usuk) dan kolaborasi penataan modul ruang dan model struktur dengan elegan, menjadikan penampilan rumah tardisional Jawa dapat dikelompokkan dalam "struktur sebagai prinsip organisasi perancangan”.

j. Konfigurasi ruang segi sembilan sebagai pengejawantahan konsep mandala dalam bentuk grid yang sederhana dan jelas, penampilan potensi estetis struktur sebagai akibat dari teknik konstruksi dalam seismic design, pemanfaatan tata letak elemen struktur yang menegaskan keseim- bangan, dan kekakuan struktur sebagai pendukung bentuk ruang, membuat penampilannya dikelompokkan dalam minimal structure.

\section{Rekomendasi}

a. Penggunaan rumah tradisional Jawa pada masa sekarang dianggap aman, apabila sistem tumpuan dibuat jepit, karena struktur rangka 3 dimensi dan sistem pembebanan mampu mengatasi getaran gaya gempa di zona gempa 3.

b. Penerapan sistem sambungan lidah alur pada struktur rangka 3 dimensi dengan kualitas kayu yang terjamin dan memiliki ketelitian teknik konstruksi sambungan dapat dimanfaatkan untuk bangunan sekarang di zona gempa 3 .

c. Perawatan berkala terhadap material kayu, komponen struktur dan konstruksi sambungan akan menjamin kehandalan kinerja struktur rumah tradisional Jawa menghadapi getaran gempa.

d. Penggunaan kayu dan rekayasa sambungannya sebagai konstruksi bangunan perlu dikembangkan untuk bangunan saat ini, terutama kebutuhan bentang lebar, inovasi metode membangun dan eksplorasi bentuk arsitektur berdasar struktur.

e. Penelitian ini mengambil fokus kajian pada perilaku dan kinerja struktur rong-rongan saja, sehingga kontribusi soko pengarak (kolom samping) terhadap kekuatan dan kestabilan rumah tradisional Jawa dapat dilakukan.

f. Sistem tumpuan (umpak dan ceblokan) pada struktur rong-rongan khususnya dan pada rumah tradisional Jawa umumnya belum dikaji perilaku dan kinerja terhadap kestabilan bangunan. Hal ini dapat dijadikan topik penelitian lanjutan. Penelitian perbandingan dapat dilakukan untuk validasi hasil penelitian, antara metode eksperimen terskala dengan simulasi komputer atau eksperimen skala penuh.

g. Penelitian sejenis untuk struktur rumah tradisional daerah atau zona gempa lain perlu dilakukan. Hal ini untuk melengkapi dan membandingkan pola struktural dan teknik bangunan melalui pattern language secara konstuktif, yang ditinjau dari gaya gempa di Indonesia.

\section{DAFTAR PUSTAKA}

Dakung, Sugiyarto., 1981, Arsitektur Tradisonal Daerah Istimewa Yogyakarta, Departemen Pendidikan dan Kebudayaan, Yogyakarta.

Depkimprawsil, 2002, Tata Cara Perencanaan Ketahanan Gempa Untuk Bangunan Gedung, SNI $03-1726-2002$. , tanpa tahun, Linuh Bali, BIC Bali. 
, Metode Pengujian Kuat Tarik Kayu di Laboratorium, SNI-03-3399-1994

, Metode Pengujian Kuat Geser Kayu di Laboratorium, SNI-03-3400-1994

, Metode Pengujian Kuat Tekan Kayu di Laboratorium, SNI-06-3958-1995

, Metode Pengujian Kuat Lentur Kayu di Laboratorium, SNI-03-3959-1993

, Metode Pengujian Modulus Elastisitas Lentur Kayu di Laboratorium, SNI-03-39601995

Metode Pengujian Modulus Elastisitas Lentur Kayu Berukuran Struktural, SNI-033972-1995

, Metode Pengujian Modulus Elastisitas Tekan dan Kuat Tekan Sejajar Serat Kayu Konstruksi Berukuran Struktural, SNI-033973-1995

, Metode Pengujian Modulus Geser Kayu Konstruksi Berukuran Struktural, SNI-033974-1995

, Metode Pengujian Kuat Lentur Kayu Konstruksi Berukuran Struktural, SNI-033975-1995

Frick, Heinz, 1997, Pola Struktural dan Teknik Bangunan di Indonesia (Suatu Pendekatan Arsitektur Indonesia melalaui Pattern Language secara Konstruktif dengan contoh Arsitektur Jawa Tengah), Penerbit Kanisius, Yogyakarta.

Frick, Heinz \& Purwanto, LMF, 1998, Sistem Bentuk Struktur Bangunan (Dasar-dasar Konstruksi dalam Arsitektur), Penerbit Kanisius, Yogyakarta.

Glasser, D.E., 1976, Structural Considerations, in Snyder, James C and Antony J Catnese (Eds), Introduction to Architecture (pp. 268 - 272), Mac Graw-Hill, New York.

Hamzuri, 1982, Rumah Tradisonal Jawa, Proyek Pengembangan Permuseuman DKI Jakarta, Departemen Pendidikan dan Kebudayaan, Jakarta.

Hossdorf, Heinz, 1974, Model Analysis of Structure (CV Amerongen, trans), Van Reinhold Co

Howard, H Seymour, 1966, Structure : an Architect's Approach, Mac Graw-Hill, New York

Indorf, P, 1991, Conceptual models of Buddhist Architecture, with Particular Reference to Southeast Asia, in Architecture Journal 1991, School of Architecture, National University of Singapore
Ismunandar K., R, 1986, Joglo Arsitektur Rumah Tradisional Jawa, Dahara Prize, Semarang.

Jumsai, Sumet, 1988, Naga; Cultural Origins in Siam and the West Pasific, Oxford Uni press

Mangunwijaya, Y.B., 1988, Pertimbangan-pertimbangan Pengaruh Alam, Gempa Bumi dalam Pengantar Fisika Bangunan, Penerbit Djambatan, Jakarta.

Shinken Co Ltd, Manual Vibration Testing System with Horizontal Slip Table, 1980.

Merati, Widiadnyana, 1990, Analisis Dimensional dan Teori Model, diktat kuliah Jurusan Teknik Sipil ITB

Nazir, M, 2003, Metode Penelitian, Ghalia Indonesia Jakarta.

Nasution, Burhan, 2001, Tipologi Arsitektur Tradisional di Daerah Gempa : Sebuah Tinjauan Struktur, Tesis Pasca Sarjana Arsitektur ITS, Surabaya.

Pedju, Ary Mochtar, 1993, Laboratorium Struktur untuk Pendidikan Arsitektur, diktat kuliah Jurusan Arsitektur ITB

Pont, Henry Maclaine, Arsitektur Jawa, alih bahas oleh Aswito Asmaningprodjo, Suprapto \& Suyono Kusumowardoyo (tidak diplubikasikan), Bandung.

Prihatmaji, Yulianto P, 2002, Kinerja Rumah Tradisional Jawa : Joglo dalam Menghadapi Gempa, paper kuliah Magister Arsitektur ITB, Bandung

, 2003, Perilaku Rumah Tradisional Jawa terhadap Gempa, Tesis Magister Arsitektur, Institut Teknologi Bandung.

2004, Tipomorfologi Struktur Rumah Tradisional Jawa ditinjau dari Gaya Gempa, Jurnal TEKNISIA FTSP Universitas Islam Indonesia, Vo. IX No. 2, Agustus 2004, ISSN: 0853-8557

Prijotomo, Josef \& Rachmawati, Murni, 1995, Petungan : Sistem Mengukur dalam Arsitektur Jawa, Gadjah Mada University Press, Yogyakarta.

Rapoport, Amos, 1969, House Form and Culture, Prentice Hall Inc, Engelwood Cliftts, New Jersey.

Ronald, Arya/Mohammad Santosa Soeleman Saragih, 1987, Joglo Building: A Study of Construction, Proportion and Structure of Royal Houses in Yogyakarta, karya penelitian, Universitas Gadjah Mada, Yogyakarta. 
Ronald, Arya, 1988, Manusia dan Rumah Jawa, Jurusan Teknik UGM, Yogyakarta.

Siddiq Suwandojo, 2001, Beberapa Tinjauan Aspek Bahan, Konstruksi dan Struktur Bangunan Tradidonal Indonesia (catatan kuliah), Magister Arsitektur, ITB.

, 2002, Struktur Bangunan Tradisional (catatan kuliah), Magister Arsitektur, ITB.

Subekti, Bambang, 1998, Upaya Mengurangi Resiko Kerusakan Akibat Gaya lateral pada Bangunan Kolonial Belanda di Bandung, Tesis Program Magister Arsitektur ITB.

Wangsadinata, Wiratman, 1988, Pengaruh Gempa terhadap perancangan Arsitektur Bangunan (makalah seminar Peranan Arsitektur dan Struktur dalam Perencanaan Bangunan Tinggi), FTSP Universitas Trisakti. 